\title{
Biomarkers of COVID-19 severity may not serve patients with polycystic ovary syndrome
}

\author{
Abu Saleh Md Moin ${ }^{1}$, Manjula Nandakumar ${ }^{1}$, Thozhukat Sathyapalan², Stephen L. Atkin ${ }^{3 \dagger}$ \\ and Alexandra E. Butler ${ }^{1 *}+($ C)
}

Keywords: Biomarkers, Polycystic ovary syndrome, COVID-19, SARS-CoV-2, Platelet degranulation, Coagulation

factors

\section{To the Editor:}

In a cohort of patients with differing severity of COVID-19 disease, including non-survivors, plasma proteomic analysis identified biomarkers of COVID-19 disease progression [1]. The top pathways identified by Shu et al. were those of platelet degranulation and the complement and coagulation cascades [1]. These identified pathways were complementary to another recent study comparing COVID-19 disease and control subjects, where proteomic panels also identified biological pathways involved in platelet degranulation and the coagulation cascade [2]. Whilst the comparison with absolute disease-free normality is relevant, an increasing proportion of the population have insulin resistant states with associated metabolic conditions; an example of such a metabolic condition is polycystic ovary syndrome (PCOS) where it has been shown that protein expression patterns may differ compared to those without PCOS [3]. Notably, in PCOS, platelet aggregation enhancement together with aberrant diminished plasma fibrinolytic activity potentially giving rise to enhanced thrombosis

\footnotetext{
*Correspondence: aeb91011@gmail.com; abutler@hbku.edu.qa ${ }^{\dagger}$ Stephen L Atkin and Alexandra E Butler are joint senior authors. ${ }^{1}$ Diabetes Research Center (DRC), Qatar Biomedical Research Institute (QBRI), Hamad Bin Khalifa University (HBKU), Qatar Foundation (QF), PO Box 34110, Doha, Qatar

Full list of author information is available at the end of the article
}

has been described $[4,5]$, with markers of coagulation being enhanced [6].

For a protein biomarker to be of value, there needs to be a clear discrimination between normal and disease condition levels. Therefore, platelet degranulation and the complement and coagulation cascade proteomic analysis was performed in women with and without PCOS to compare with these pathways described in COVID-19 disease [1].

243 subjects (146 PCOS and 97 control women) were recruited to the local PCOS biobank (ISRCTN70196169) [3] in the Department of Endocrinology, Hull and East Yorkshire Hospitals NHS Trust. The Rotterdam consensus diagnostic criteria were used to diagnose PCOS. Proteins that were described for platelet degranulation (18 of 27 proteins) and the complement and coagulation cascades (16 of 19 proteins) [1] were measured using the Slow Off-rate Modified Aptamer (SOMA)-scan plasma protein measurement [7], shown in Table 1. Statistics were performed using Graphpad Prism 8.0.

As reported previously [3], whilst cohorts were agematched, the PCOS women differed in having increased systolic and diastolic blood pressure and waist circumference $(p<0.05)$, together with increased insulin resistance, increased androgens and $\mathrm{C}$-reactive protein (CRP) $(\mathrm{p}<0.001)$, indicative of metabolic dysfunction.

For the 46 protein biomarkers described by Shu et al. [1], 34 were available for measurement in the Somalogic platform: 4 of 18 were found to differ in PCOS for platelet

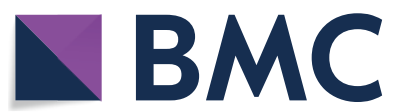

(c) The Author(s) 2021. This article is licensed under a Creative Commons Attribution 4.0 International License, which permits use, sharing, adaptation, distribution and reproduction in any medium or format, as long as you give appropriate credit to the original author(s) and the source, provide a link to the Creative Commons licence, and indicate if changes were made. The images or other third party material in this article are included in the article's Creative Commons licence, unless indicated otherwise in a credit line to the material. If material is not included in the article's Creative Commons licence and your intended use is not permitted by statutory regulation or exceeds the permitted use, you will need to obtain permission directly from the copyright holder. To view a copy of this licence, visit http://creativeco mmons.org/licenses/by/4.0/. The Creative Commons Public Domain Dedication waiver (http://creativecommons.org/publicdomain/ zero/1.0/) applies to the data made available in this article, unless otherwise stated in a credit line to the data. 
Table 1 Proteins identified as being altered in COVID-19 disease categorized according to A, platelet degranulation; B, complement and coagulation cascades in non-COVID infected polycystic ovary syndrome (PCOS) and control women

a PLATELET DEGRANULATION

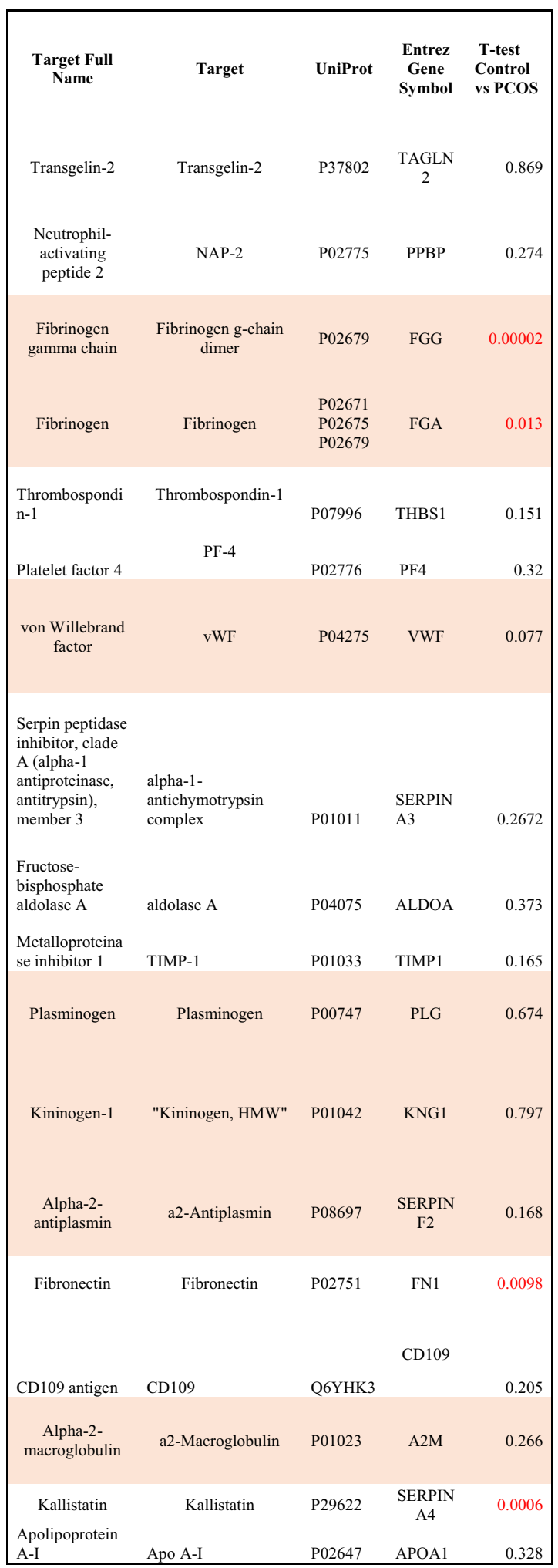

b COMPLEMENT AND COAGULATION CASCADES

\begin{tabular}{|c|c|c|c|c|}
\hline $\begin{array}{l}\text { Target Full } \\
\text { Name }\end{array}$ & Target & UniProt & $\begin{array}{l}\text { Entrez } \\
\text { Gene } \\
\text { Symbol }\end{array}$ & $\begin{array}{l}\text { T-test } \\
\text { Control vs } \\
\text { PCOS }\end{array}$ \\
\hline $\begin{array}{l}\text { Fibrinogen } \\
\text { gamma chain }\end{array}$ & $\begin{array}{l}\text { Fibrinogen g- } \\
\text { chain dimer }\end{array}$ & P02679 & FGG & 0.00002 \\
\hline Fibrinogen & Fibrinogen & $\begin{array}{l}\text { P02671, } \\
\text { P02675 } \\
\text { P02679 }\end{array}$ & FGA & 0.013 \\
\hline $\begin{array}{l}\text { Complement } \\
\text { factor I }\end{array}$ & Factor I & P05156 & CFI & 0.00000002 \\
\hline $\begin{array}{l}\text { von } \\
\text { Willebrand } \\
\text { factor }\end{array}$ & vWF & P04275 & VWF & 0.077 \\
\hline $\begin{array}{l}\text { Coagulation } \\
\text { factor IX }\end{array}$ & $\begin{array}{l}\text { Coagulation } \\
\text { Factor IX }\end{array}$ & P00740 & F9 & $<0.00001$ \\
\hline $\begin{array}{l}\text { Complement } \\
\text { factor } \mathrm{H}\end{array}$ & Factor $\mathrm{H}$ & P08603 & $\mathrm{CFH}$ & $<0.000000001$ \\
\hline $\begin{array}{l}\text { Complement } \\
\text { component } \\
\text { C9 }\end{array}$ & C9 & P02748 & C9 & 0.00002 \\
\hline Vitronectin & Vitronectin & P04004 & VTN & 0.393 \\
\hline Plasminogen & Plasminogen & P00747 & PLG & 0.674 \\
\hline Kininogen-1 & $\begin{array}{l}\text { "Kininogen, } \\
\text { HMW" }\end{array}$ & P01042 & KNG1 & 0.797 \\
\hline $\begin{array}{l}\text { Alpha-2- } \\
\text { antiplasmin }\end{array}$ & $\begin{array}{c}\text { a2- } \\
\text { Antiplasmin }\end{array}$ & P08697 & $\begin{array}{c}\text { SERPINF } \\
2\end{array}$ & 0.168 \\
\hline $\begin{array}{l}\text { Complement } \\
\text { component } \\
\text { C4B }\end{array}$ & & $\begin{array}{l}\text { P0C0L4 } \\
\text { P0C0L5 } \\
\text { P0C0L4 } \\
\text { P0C0L5 }\end{array}$ & C4B & 0.687 \\
\hline $\begin{array}{l}\text { Plasma } \\
\text { serine } \\
\text { protease } \\
\text { inhibitor }\end{array}$ & PCI & P05154 & $\begin{array}{l}\text { SERPINA } \\
5\end{array}$ & 0.038 \\
\hline $\begin{array}{l}\text { Heparin } \\
\text { cofactor } 2\end{array}$ & $\begin{array}{l}\text { Heparin } \\
\text { cofactor II }\end{array}$ & P05546 & $\begin{array}{c}\text { SERPIND } \\
1\end{array}$ & 0.00003 \\
\hline $\begin{array}{l}\text { Vitamin K- } \\
\text { dependent } \\
\text { protein C }\end{array}$ & Protein C & P04070 & PROC & 0.511 \\
\hline $\begin{array}{l}\text { Alpha-2- } \\
\text { macroglobuli } \\
\text { n }\end{array}$ & $\stackrel{\text { a2- }}{\text { Macroglobulin }}$ & P01023 & $\mathrm{A} 2 \mathrm{M}$ & 0.266 \\
\hline
\end{tabular}


Table 1 (continued)

Students' t-test was used to determine differences between protein levels. Proteins that differed significantly $(p<0.05)$ are shown in red font. Proteins that are common to both the platelet degranulation and the complement/coagulation cascades are shaded in orange

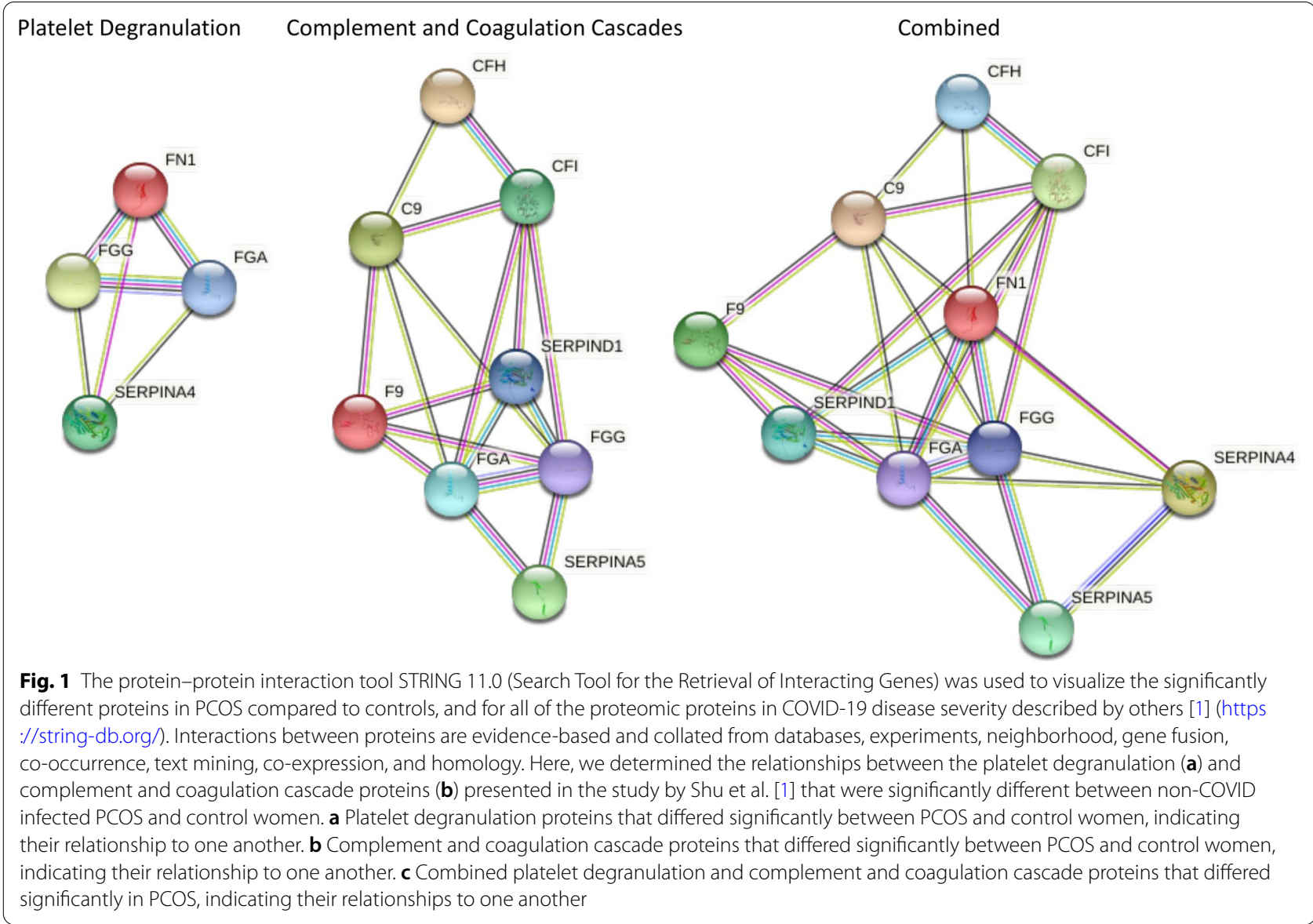

degranulation [fibrinogen-gamma chain $(\mathrm{p}=0.00002)$, fibrinogen $(p=0.013)$, fibronectin $(p=0.0098)$ and kallistatin $(p=0.0006)]$, whilst 8 of 16 proteins for complement and coagulation cascade (fibrinogen-gamma chain $(p=0.00002)$, fibrinogen $(p=0.013)$, complement factor $1(\mathrm{p}=0.00000002)$, coagulation factor IX $(\mathrm{p}<0.00001)$, complement factor $\mathrm{H}(\mathrm{p}<0.000000001)$, complement component $\mathrm{C} 9(\mathrm{p}=0.00002)$, plasma serine protease inhibitor $(\mathrm{p}=0.038)$ and heparin cofactor $2(\mathrm{p}=0.00003)$ (Table 1$)$. Moreover, those proteins that significantly differed between PCOS and controls share a close relationship to one another, as shown by the protein-protein interaction tool STRING (Search Tool for the Retrieval of Interacting Genes) pathways (Fig. 1).

The significant difference seen in PCOS compared to controls indicates the need for validation of such markers in the non-COVID-19 infected population before they can be considered as biomarkers for COVID-19 and its severity. Notably, based on the indication that COVID-19 severity can be related to these markers, their detection in a PCOS COVID-19 positive patient may give a false impression of severity, potentially leading to the introduction of inappropriate therapy; conversely, the detection of these specific markers in women with PCOS may actually indicate that more proactive intervention is required, as these women may have a propensity for increased COVID-19 disease severity [8].

Limitations of the study include that the Somalogic panel did not include all of the proteins that were previously reported, and the proteomic analysis differed so may not be directly comparable to the Shu et al. study [1] or others [2]. Nonetheless, the majority of proteins were common to both proteomic platforms.

In conclusion, 12 of 34 protein biomarkers contained within the platelet degranulation and complement and coagulation cascades and purported to indicate disease progression in patients infected with COVID-19, differed between non-COVID-19 infected PCOS and control 
women. This indicates that validation of such proposed COVID-19 specific biomarkers is a necessity, although it is unclear if this places PCOS women at increased risk of more severe COVID-19 disease.

\section{Acknowledgements}

None.

\section{Authors' contributions}

ASMM, MN and AEB analyzed the data and wrote the manuscript. TS supervised clinical studies and edited the manuscript. SLA contributed to study design, data interpretation and the writing of the manuscript. All authors reviewed the final version of the manuscript. AEB is the guarantor of this work. All authors read and approved the final manuscript.

\section{Funding}

No funding was received to perform this study.

\section{Availability of data and materials}

All the data for this study will be made available upon reasonable request to the corresponding author.

\section{Ethics approval and consent to participate}

The Newcastle \& North Tyneside Ethics committee approved this study that was conducted according to the Declaration of Helsinki. All study participants signed an informed consent form prior to participation.

\section{Consent for publication}

All authors gave their consent for publication.

\section{Competing interests}

No authors have any conflict of interest or competing interests to declare.

\section{Author details}

1 Diabetes Research Center (DRC), Qatar Biomedical Research Institute (QBRI), Hamad Bin Khalifa University (HBKU), Qatar Foundation (OF), PO Box 34110 Doha, Qatar. ${ }^{2}$ Academic Endocrinology, Diabetes and Metabolism, Hull York
Medical School, Hull, UK. ${ }^{3}$ Royal College of Surgeons in Ireland Bahrain, Adliya, Kingdom of Bahrain.

Received: 23 January 2021 Accepted: 27 January 2021

Published online: 11 February 2021

\section{References}

1. Shu T, Ning W, Wu D, Xu J, Han Q, Huang M, et al. Plasma proteomics identify biomarkers and pathogenesis of COVID-19. Immunity. 2020;53(5):1108-22.e5.

2. Overmyer KA, Shishkova E, Miller IJ, Balnis J, Bernstein MN, Peters-Clarke TM, et al. Large-Scale multi-omic analysis of COVID-19 severity. Cell Syst. 2020. https://doi.org/10.1101/2020.07.17.20156513.

3. Moin ASM, Sathyapalan T, Atkin SL, Butler AE. Renin-angiotensin system overactivation in polycystic ovary syndrome, a risk for SARS-CoV-2 infection? Metabolism open. 2020;7:100052.

4. Mak W, Dokras A. Polycystic ovarian syndrome and the risk of cardiovascular disease and thrombosis. Semin Thromb Hemost. 2009:35(7):613-20.

5. Yildiz BO, Haznedaroğlu IC, Kirazli S, Bayraktar M. Global fibrinolytic capacity is decreased in polycystic ovary syndrome, suggesting a prothrombotic state. J Clin Endocrinol Metab. 2002;87(8):3871-5.

6. Oral B, Mermi B, Dilek M, Alanoğlu G, Sütçü R. Thrombin activatable fibrinolysis inhibitor and other hemostatic parameters in patients with polycystic ovary syndrome. Gynecol Endocrinol. 2009;25(2):110-6.

7. Kahal H, Halama A, Aburima A, Bhagwat AM, Butler AE, Grauman J, et al. Effect of induced hypoglycemia on inflammation and oxidative stress in type 2 diabetes and control subjects. Sci Rep. 2020;10(1):4750.

8. Juusela A, Nazir M, Gimovsky M. Two cases of coronavirus 2019-related cardiomyopathy in pregnancy. Am J Obstet Gynecol MFM. 2020;2(2):100113

\section{Publisher's Note}

Springer Nature remains neutral with regard to jurisdictional claims in published maps and institutional affiliations.
Ready to submit your research? Choose BMC and benefit from:

- fast, convenient online submission

- thorough peer review by experienced researchers in your field

- rapid publication on acceptance

- support for research data, including large and complex data types

- gold Open Access which fosters wider collaboration and increased citations

- maximum visibility for your research: over $100 \mathrm{M}$ website views per year

At $\mathrm{BMC}$, research is always in progress.

Learn more biomedcentral.com/submissions 